\title{
Scrutinizing the current practice of the environmental risk assessment of GM maize applications for cultivation in the EU
}

\author{
Marion Dolezel ${ }^{1 *}$, Marianne Miklau', Angelika Hilbeck², Mathias Otto³, Michael Eckerstorfer ${ }^{1}$, \\ Andreas Heissenberger ${ }^{1}$, Beatrix Tappeser ${ }^{3}$ and Helmut Gaugitsch ${ }^{1}$
}

\begin{abstract}
Purpose: The prevailing controversies on the potential environmental risks of genetically modified organisms [GMOs] still fuel ongoing discussions among European Union [EU] member states, risk assessors, applicants and scientists, even several years after the commercial introduction of GMOs. The disagreements mainly derive from the current risk assessment practice of GMOs and differences in the perceived environmental risks. Against this background, the aim of this study was to scrutinize the current practice of environmental risk assessment [ERA] of several GMO applications currently pending for authorisation in the EU.
\end{abstract}

Methods: We analysed the data presented for three assessment categories of the ERA of genetically modified [GM] maize applications for cultivation in the European Union: the agronomic evaluations and the assessments of the effects of GM maize on target organisms and of its potential adverse effects on non-target organisms.

Results: Major shortcomings causing considerable uncertainties related to the risk assessment were identified in all three categories. In addition, two principles of Directive 2001/18/EC are largely not fulfilled - the consideration of the receiving environment and the indirect effects, as mediated, e.g. by the application of the complementary herbicide in the case of herbicide-tolerant GM maize.

Conclusions: We conclude that the current practice of ERA does not comprehensively fulfil the scientific and legal requirements of Directive 2001/18/EC, and we propose improvements and needs for further guidance and development of standards. The recommendations address likewise applicants, risk assessors as well as decision makers.

\section{Background}

Authorisation of genetically modified organisms [GMOs] in Europe is regulated by Directive 2001/18/EU [1] and Regulation (EC) 1829/2003 [2], respectively. The objective of Directive 2001/18/EC [1] is to protect human health and the environment when a GMO is placed on the market as or in products (Article 1). The focus is on the preventive action due to the ability of living organisms to reproduce and the irreversibility of the release of GMOs in the environment. Thus, the Directive requires a case-by-case approach to the environmental risk assessment [ERA] to be carried out prior

\footnotetext{
* Correspondence: marion.dolezel@umweltbundesamt.at

'Umweltbundesamt GmbH, Spittelauer Laende 5, 1090 Vienna, Austria

Full list of author information is available at the end of the article
}

to decisions on applications. Annex II of the Directive defines the general principles of the ERA, the steps, the methodology and the conclusions to be drawn on the potential environmental impact from the release or the placing of GMOs on the market. Annexes III and IV lay down the information requirements to be included in applications. When performing the ERA, the applicant has to consider the 'risks to human health and the environment, whether direct or indirect, immediate or delayed, which the deliberate release or the placing on the market of GMOs may pose' (Annex II) [1]. 'Direct effects' are the effects resulting from the GMO itself without an intermediate chain of events. 'Indirect effects' are the effects 'occurring through a causal chain of events, through mechanisms such as interactions with 
other organisms, transfer of genetic material, or changes in use or management of the crop' (Annex II) [1]. 'Immediate effects' refer to the effects 'which are observed during the period of the release and use of the GMO', whilst 'delayed effects' are the effects 'which may become apparent as a direct or indirect effect either at a later stage or after termination of the release' [1].

Similarly, Regulation (EC) 1829/2003 [2] requires 'a technical dossier for the application of a GMO supplying the information required by Annexes III and IV of Directive 2001/18/EC and information and conclusions about the risk assessment carried out in accordance with the principles set out in Annex II to Directive $2001 / 18 / E C^{\prime}$ if the scope of the notification covers food or feed containing or consisting of GMOs (Article 5) [2]. The information requirements as defined by Annex III in the Directive are also referred to in the guidance document of the European Food Safety Authority [EFSA] [3], although they differ to some extent in structure and detail.

For many years, the authorisation of genetically modified plants [GMPs] in the European Union [EU] has been a controversial issue. Regulation (EC) 1829/2003 [2] introduced a centralised procedure of authorisation by the European Commission, which includes the consultation of the European Member States [MS] and a scientific evaluation conducted by EFSA. If a GMO application encompasses cultivation, EFSA nominates a MS to conduct an initial appraisal of the ERA submitted by the applicant. On the basis of this appraisal and complemented with input from MS, EFSA carries out a scientific evaluation and issues an opinion. Based on this opinion, the European Commission drafts a decision to be voted on by MS. Despite the new legislation $[1,2,4]$ and efforts to strengthen risk assessment guidance and to promote exchange among the scientific experts of the EFSA and European MS, no qualified majorities for decisions on import and processing or cultivation of GMPs could be reached so far. With the exception of genetically modified [GM] carnations, all final decisions have been taken by the European Commission unilaterally.

Except for a GM potato in 2010, no GM crops have been approved for cultivation since 1998. Instead, several import and cultivation bans have been enacted by different European MS. For instance, since 1999, the cultivation of Bacillus thuringiensis [Bt] maize MON810 was banned in Austria, France, Hungary, Luxemburg, Greece and Germany. Since 2009, at the political level, discussions are underway to shift the responsibility for final approval of the cultivation of GM crops to the national level of the individual MS [5].

The difficulties in decision making at the EU level have to be contextualized in light of the controversies among risk assessors, decision makers and scientists in the EU MS regarding the quality and quantity of the data submitted for the legally required ERA of GMPs. On a scientific level, controversies arose on the chosen methodology of the ERA, the tested endpoints, the duration of tests and, last but not least, the chosen test organisms [6-9].

The 'centralisation' of the authorisation procedure and the continuously positive opinions by EFSA considering the ERAs of the applications as sufficient led to a considerable dispute among MS on the presumed safety of GMPs. It has also been criticised by EU MS that the quality of the submitted data varies considerably, and improvements of the ERA based on common standards are being demanded [10-13]. These controversies stress the need for further harmonisation of practices and methods of assessing the environmental risks of GMPs, in particular regarding the impact on non-target organisms [NTOs], potential long-term effects and indirect effects resulting from potential changes in agricultural management techniques.

Against this background, the Environment Agency Austria was commissioned by the German Federal Agency for Nature Conservation to carry out a study with the aim of evaluating the current practice of the ERA of GMPs in the EU, describing the compliance with legal and scientific requirements, identifying possible shortcomings and proposing improvements of the data basis and the ERA process where needed [14]. In this article, the most important findings regarding the evaluation of GM maize applications are presented. More details for GM maize and the results for other GM crops, like herbicide-tolerant [HT] oilseed rape and GM potato with altered starch composition, can be found in the full report [14].

\section{Materials and methods}

\section{Selection of material for analysis}

Seven applications of GM maize including cultivation in their scope, which have been submitted under the relevant EU legislation [1,2] at that time, were selected for this analysis. The selected applications of GMPs comprise traits representative for GMPs of interest for the European market, insect resistance and herbicide tolerance (Table 1). The documents of the original application as well as any additional information submitted by the applicants before 31 December 2007 were accounted for. The selection includes both single-trait events (e.g. maize MON810) and stacked varieties with different combined events (e.g. maize NK603 × MON810).

The aim of the study was to evaluate the data basis put forward by applicants for the ERA and its implications for conducting an ERA. This data basis reflects the information available for the Competent Authorities 
Table 1 Overview of the applications selected for the study (status: December 2007)

\begin{tabular}{|c|c|c|c|c|}
\hline GMP & Relevant legislation & Scope & Application number & GM traits \\
\hline Maize MON810 & $\mathrm{D} 90^{\mathrm{a}, \mathrm{b}}$ & Seed $(C U, P)$ & $C / F / 95 / 12 / 02$ & $\mathrm{IR}$ \\
\hline Maize Bt11 & $\mathrm{D} 01^{\mathrm{b}, \mathrm{c}}$ & $F O, F E, I P, C U$ & $C / F / 96 / 05 / 10$ & $\mathrm{IR}, \mathrm{HT}$ \\
\hline Maize 1507 & $\mathrm{D} 01^{\mathrm{b}}$ & $C U, I, P^{e}$ & C/ES/01/01 & $\mathrm{IR}, \mathrm{HT}$ \\
\hline Maize NK603 & $R^{b}$ & $F O, F E, I, P, C U$ & EFSA/GMO/NL/2005/22 & HT \\
\hline Maize 59122 & $R^{d}$ & $F O, F E, I, P, C U$ & EFSA/GMO/NL/2005/23 & $\mathrm{IR}, \mathrm{HT}$ \\
\hline Maize $1507 \times$ NK603 & $R^{d}$ & $F O, F E, I, P, C U$ & EFSA/GMO/UK/2005/17 & $\mathrm{IR}, \mathrm{HT}$ \\
\hline Maize NK603 × MON810 & $R^{d}$ & $\mathrm{CU}$ & EFSA/GMO/NL/2005/26 & $\mathrm{IR}, \mathrm{HT}$ \\
\hline
\end{tabular}

D90, Directive 90/220EEC; D01, Directive 2001/18/EC; R, Regulation (EC) No. 1829/2003; FO, food use; FE, feed use; l, import; P, processing; IP, industrial processing and uses; CU, cultivation; Seed, seed production, $\mathrm{HT}$, herbicide tolerance; IR, insect resistance.

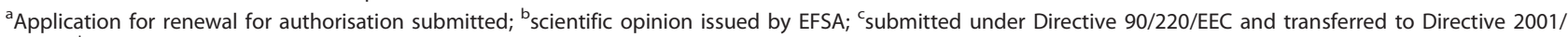

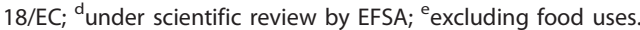

[CAs] of Member States when performing their risk assessment. We point out that the intention of this analysis was not to draw overall conclusions on the potential environmental risks of the GMPs linked with the applications. For this reason and because EFSA issues its opinions after the MS, we decided not to take the EFSA's opinions of the applications reviewed into account. Thus, the analysis exclusively focused on the ERA and the respective data submitted by the applicants in support of their ERA. The data presented for the assessment of effects on human health were omitted from the analysis due to the lack of direct relevance for environmental risks.

\section{Rationale and analysis of applications}

The procedure of the ERA, including all necessary steps from hazard identification to the overall risk characterisation, is laid down in Annex II of EU Directive 2001/ $18 / \mathrm{EC}$ and the supplementing guidance notes [15]. Moreover, in its Annexes, in particular Annex II.D.2 and Annex III.B, EU Directive 2001/18/EC specifies information requirements which may be necessary to carry out the ERA. Similarly, these information points are required to be included in applications according to Regulation (EU) 1829/2003. In addition, the EFSA guidance document [3] provides specific areas of risk which have to be addressed during the ERA. It is the quality of these information elements which was of main concern in the study commissioned by the German Federal Agency for Nature Conservation [14], whose purpose was to critically analyse the data generation by the applicant in order to perform an ERA and, thereby, the information basis on which decisions have to be made by CAs rather than the methodology of the ERA itself. Consequently, this manuscript does not elaborate on the general methodology of the ERA, its components and underlying concepts, but presents an analysis of the data on which the ERA, the core activity of risk analysis, is based upon.
As the information elements slightly differ in structure and detail between EU Directive 2001/18/EC and the EFSA guidance document [3], we combined them into ten assessment categories: molecular characterisation, expression, agronomics, composition, dissemination and related processes, target organisms, non-target organisms, biogeochemical cycles, change in land use and cultivation technique, and risk management including monitoring [14]. Among the ten categories studied, three selected ones are presented in this article: (1) assessment of the agronomic characteristics of the GMP, (2) assessment of effects on and mediated by target organisms [TOs] and (3) assessment of interactions of the GMP with NTOs.

The analysis of each assessment category followed a common approach. In principle, the analysis focused on studies provided by and carried out on behalf of the applicants. Most of these information are not published peer-reviewed. If the applicant cites or refers to such studies, in a first step, their availability and documentation within the applications was checked. In a second step, these studies were assessed to comply with good scientific practice, including appropriate methodology, experimental design, and statistical analyses and reporting, as well as with criteria laid down in the EFSA guidance document [3]. In accordance with the case-bycase approach outlined in Directive 2001/18/EC (Preamble, points 18 and 19), we considered data on the respective GMP (i.e. the specific transformation event) mandatory for the assessment and thus focused on the data sets specifically generated and presented for the GMP in question. Consequently, only studies conducted with the GMP or with the relevant proteins were further analysed regarding the following aspects:

\section{(1) Agronomic characteristics of the GMP}

Number of field locations; number of years and representativeness of the selected locations with regard to the intended market release (in all cases the entire EU); characterisation of individual locations; choice of 
comparators (controls); use of appropriate pesticide management in trials with HT GMPs; and relevance of estimated agronomic parameters. The analysis of field data focused on field trials conducted in Europe as these are considered to have the highest relevance if a GMP is to be cultivated in the EU

\section{(2) Effects on and mediated by TOs}

Effectiveness of control; occurrence of secondary pests; effects due to changes in food/prey availability; and resistance development.

\section{(3) Interactions of the GMP with NTOs}

Exposure assessment; test strategy and selection of test organism (e.g. assessment of relevant functional groups); toxicological endpoints; multi-trophic effects; and effects on species of conservation concern. In this category, laboratory studies using the introduced protein (e.g. Cry protein), or in some cases parts of the GMP (e.g. pollen), were distinguished from whole-plant studies under containment and whole-plant studies in the field. Additionally, and only for this category, the published literatures cited in the applications as supporting evidence were analysed for their relevance (e.g. type of test substance or GMP used) and their completeness. Under completeness, we checked whether the citations comprised all relevant studies at the time when the application was submitted by the applicant and, thus, whether the state of scientific knowledge was represented.

\section{Results}

\section{Analysis of the assessment of agronomic characteristics} of the GMP

Data for the assessment of the agronomic performance of the GMP were in all cases generated by conducting field trials at different locations either in one country or in different countries or even continents. Generally, no rationale or criteria were given for the selection of the field sites. For GM maize MON810 and NK603 $\times$ MON810, no agronomic data obtained under European conditions were presented (Table 2).

Information on field trial locations was generally restricted to stating the name of the location and the country. Climatic data were presented in the applications of GM maize 1507, 59122 and $1507 \times$ NK603; for maize 59122 and maize $1507 \times$ NK603, information on the soil type at a specific location and a map of the location were also presented (see [14]).

In a given year, field trials were conducted in one (1995; maize Bt11; 2002: maize 1507; 2000-2002: maize NK603; 2003: maize 59122) or two (2004: maize 59122; 2003: maize $1507 \times$ NK603) or three (2000: maize 1507) European countries (Table 2). Except for GM maize 59122 in Bulgaria, none of the field trials was carried out for more than two consecutive growing seasons at a given location.

In $60 \%$ of genetically modified herbicide-tolerant (GMHT) maize applications with European field trials, the agronomic performance was tested in the absence of the corresponding broad-spectrum herbicides. For GM maize 1507 and 59122, the respective herbicide treatments were included (Table 2) in the field trial design. However, for GM maize 1507, the potential differences between the herbicide-treated GM maize and the untreated controls were not statistically evaluated in one year (2000), and no herbicide treatment was included in the other year of field trials (2002). For GM maize 59122, agronomic parameters were assessed in non-treated GMPs in all years and at all sites.

The assessment of the agronomic performance of the GMP included plant growth and development, plant morphology, plant health and yield using a broad range of different parameters. Both, quantitative (e.g. 'yield')

Table 2 Overview of non-European and European field trials for the collection of agronomic data for GMPs

\begin{tabular}{|c|c|c|c|}
\hline GMP & Years: non-European countries & Years: European countries/no. of locations & $\begin{array}{l}\text { Herbicide applied } \\
\text { (European trials only) }\end{array}$ \\
\hline Maize MON810 & - & - & - \\
\hline Maize $B t 11$ & - & 1995: FR/- & glu- \\
\hline \multirow[t]{2}{*}{ Maize 1507} & - & 2000: $F R+I T+B G / 3+2+1$ & glu+/glu- ${ }^{a}$ \\
\hline & & 2002: ES/3 & glu- \\
\hline \multirow[t]{2}{*}{ Maize NK603 } & 1999: US & 2000-2001: DE/4 & gly- \\
\hline & & 2002: FR/4 & gly- \\
\hline \multirow[t]{2}{*}{ Maize 59122} & 2002/2003: CL & 2003: BG/3 & glu+/glu- ${ }^{b}$ \\
\hline & 2003: US, CA & 2004: $B G+E S / 3+3$ & \\
\hline Maize $1507 \times$ NK603 & - & 2003: $\mathrm{BG}+\mathrm{ES} / 2+3$ & gly + fb glu+ \\
\hline Maize NK603 × MON810 & 2002: US & - & - \\
\hline
\end{tabular}

Two-letter country codes refer to ISO 3166-1 alpha-2 codes (IT, Italy; ES, Spain; FR, France; BG, Bulgaria; DE, Germany; CA, Canada; CL, Chile; US, United States). '-', no data/information provided in the application; glu+, treatment with glufosinate; glu-, no treatment with glufosinate; gly+, treatment with glyphosate; gly-, no treatment with glyphosate; fb, followed by.

${ }^{a}$ No statistics applied; ${ }^{b}$ agronomic parameters were assessed in non-treated plants only. 
and qualitative (e.g. 'leaf colour or shape') parameters, were assessed by the applicants (see [14]). The measured parameters were not consistent across all GM maize applications.

Insect damage of the GMP was evaluated in $29 \%$ of GM maize applications with field trials in Europe (Table 3). No evaluation of insect damage under European field conditions was carried out for maize events MON810 and NK603 $\times$ MON810. In the case of maize Bt11, assessment of insect damage in one European country was stated, but no data were presented in the application.

The infestation rates of pests were evaluated by visual observation and a qualitative rating on a 1 to 6 or a 1 to 9 scale. In the applications of GM maize 1507 and NK603, additionally, quantitative methods were used, such as assessing the length of the insect tunnels in the maize stalks or ears (Table 3).

For insect-resistant [IR] maize applications with field trials in Europe, the pest species assessed in the insect damage recording were specified only in the case of maize 1507 , although not in all years. For this IR maize and also maize NK603, although the latter conferring herbicide tolerance only, the infestation rate specifically caused by the European corn borer (Ostrinia nubilalis) was evaluated. In these two applications, also the Mediterranean corn borer or pink borer (Sesamia sp.) was evaluated, but also not at all sites. In no case was reference made to the pest insect pressure of the respective year and location. With the exception of maize 1507, it was never indicated whether the background infestation levels of the TOs in the control plants were sufficient to demonstrate a relevant level of control by the GMP.

\section{Analysis of the assessment of effects on and mediated by target organisms}

In applications of HT maize, no TO (i.e. target weeds) was identified. TOs (i.e. target pest insects), however, were addressed in applications of IR maize. In applications of IR maize expressing the Cry1Ab toxin (maize MON810, maize Bt11, maize NK603 $\times$ MON810), $O$. nubilalis and Sesamia spp. were indicated as TOs. The applicant of Bt11 maize listed also other lepidopteran maize pests occurring in the UK, such as Acronicta rumicis, Agrotis spp. and Autographa gamma, as TOs. For maize expressing the Cry1F toxin (maize 1507, maize $1507 \times$ NK603), O. nubilalis and Sesamia spp. were listed as TOs. For maize 59122 expressing a binary toxin (Cry34Ab1/Cry35Ab1), the Western corn rootworm (Diabrotica virgifera virgifera) was indicated as the sole TO of this GMP in the EU.

In $67 \%$ of IR maize applications, data on the specificity of the respective Cry proteins to TOs were provided (Table 4). However, in these cases, the applicant provided data produced to demonstrate the equivalence of the

Table 3 Insect damage evaluated in European field trials for the assessment of agronomic traits of the GMP

\begin{tabular}{|c|c|c|c|c|}
\hline GMP & $\begin{array}{l}\text { European Field trial } \\
\text { (year/country) }\end{array}$ & Parameter assessed & Method & Insect pests assessed \\
\hline Maize MON810 & - & - & - & - \\
\hline Maize $B+11$ & $1995 / \mathrm{FR}^{\mathrm{a}}$ & - & - & - \\
\hline \multirow[t]{3}{*}{ Maize 1507} & 2000/FR, IT, BG & Infestation & 1-9 scale, v. e. & - \\
\hline & 2002/ES & Infestation & 1-9 scale, v. e. & - \\
\hline & & Insect tunnels in stalks & Insect tunnelling length (cm) & $\begin{array}{l}\text { O. nubilalis, Sesamia sp. (2 of } 3 \\
\text { sites) }\end{array}$ \\
\hline \multirow[t]{7}{*}{ Maize NK603 } & 2000/DE & Infestation & 1-6 scale, v. e. & O. nubilalis \\
\hline & & $\begin{array}{l}\text { Difference to other } \\
\text { insects }\end{array}$ & Yes/no class. & - \\
\hline & 2001/DE & Infestation & 1-6 scale, v.e. & O. nubilalis \\
\hline & & $\begin{array}{l}\text { Difference to other } \\
\text { insects }\end{array}$ & Yes/no class. & - \\
\hline & 2002/FR & Abundance of larvae $\mathrm{e}^{\mathrm{b}}$ & Larvae per stalk/ear & $\begin{array}{l}\text { O. nubilalis ( } 4 \text { sites) } \\
\text { Sesamia sp. ( } 3 \text { sites) }\end{array}$ \\
\hline & & Borer tunnels ${ }^{c}$ & $\begin{array}{l}\text { Length of borer tunnelling in } \\
\text { stalk/ear }\end{array}$ & \\
\hline & & $\%$ damaged ears ${ }^{c}$ & & \\
\hline Maize 59122 & 2003/BG, 2004/ES, BG & Infestation & 1-9 scale, v. e. & - \\
\hline Maize $1507 \times$ NK603 & 2003/ES, BG & Infestation & 1-9 scale, v. e. & - \\
\hline $\begin{array}{l}\text { Maize NK603 } \times \\
\text { MON810 }\end{array}$ & - & - & - & - \\
\hline
\end{tabular}

'-', no data provided; v.e., visual estimation; class., classification.

${ }^{a}$ Evaluated but no data provided; ${ }^{b}$ for each pest species; ${ }^{c}$ for both pest species. 
Table 4 Studies evaluating the efficacy of the GMP in IR GM maize applications

\begin{tabular}{|c|c|c|c|}
\hline GMP & Cry protein expressed in GMP & Test substance used in ERA & Pest species evaluated in ERA \\
\hline Maize MON810 & CrylAb & - & - \\
\hline Maize Bt11 & CrylAb & Plant and bacterial proteins & ECB, CEW \\
\hline \multirow[t]{3}{*}{ Maize 1507} & Cry1F & 1507 maize plants & $E C B, M C B$ \\
\hline & Cry1F & Plant and bacterial proteins & ECB, CEW, TBW, FAW, BCW \\
\hline & Cry1F & 1507 maize plants & MCB \\
\hline \multirow[t]{3}{*}{ Maize 59122} & Cry34Ab1/Cry35Ab1 & Bacterial proteins & SCR \\
\hline & Cry34Ab1/Cry35Ab1 & Bacterial proteins & CEW, ECB, BCW SCR, WCR, NCR, CLA \\
\hline & Cry34Ab1/Cry35Ab1 & Bacterial proteins & CEW, ECB, NCR, WCR, CBW, CLA \\
\hline Maize $1507 \times$ NK603 & Cry1F & See maize 1507 & See maize 1507 \\
\hline Maize NK603 × MON810 & CrylAb & - & - \\
\hline
\end{tabular}

plant-expressed proteins to bacteria-expressed proteins, for instance by determining bioactivity. Insect bioassays on pest species were used to conclude on the bioactivity. Data from bioassays using the actual TOs and the respective GM maize plant material for which approval was sought were not provided, with the exception of maize 1507. However, we consider the efficacy data for maize 1507 as not scientifically robust due to the fact that the demonstration of the capability of 1507 maize to control TOs rested on a study presenting two mortality values from a single, non-replicated study at one location in one year in addition to one study, which did not fulfil minimal scientific requirements in terms of sample size, replication and statistical analysis. Studies showing reliable and sustainable control of Sesamia nonagrioides have not been presented by the applicant of 1507 maize, and robust data on the degree of mortality related to different growth stages and tissues of Cry1F maize were not presented (see [14]).

The applications of the stacked events contained no studies with the GMPs in question and cited the studies submitted for the respective single-event IR maize application described above. The potential development of resistance of TOs was taken into account in all applications of IR GMPs. In each case, insect resistance management plans were included for O. nubilalis (GM maize expressing the Cry1Ab or Cry1F toxins) and for Diabrotica spp. (GM maize 59122). No resistance management plan was provided or discussed for Sesamia spp. in the Mediterranean region or for any other listed target insect organism. For HT GMPs, potential adverse environmental effects resulting from the development of resistant weeds were not considered.

\section{Analysis of the assessment of interactions of the GMP with non-target organisms}

All applicants referred to studies assessing the exposure and/or effects of the respective GMP on NTOs.
However, the number of studies and their quality varied significantly among the applications (Table 5). In none of the GM maize applications was a specific evaluation of the different exposure pathways of different NTOs in different environmental media (e.g. vegetation, soil and water) conducted. In $43 \%$ of the applications, the exposure of some organisms or groups of organisms to the GMP was discussed in the ERA (Table 5). In the application of maize $B t 11$, published studies describing the exposure of Monarch butterflies to B. thuringiensis maize in the USA were cited, and the applicant referred to published and unpublished studies on the effects of the Cry1Ab toxin on Lepidoptera and non-lepidopteran NTOs. No specific exposure values for individual species, regardless whether in Europe or elsewhere, were calculated or assessed in any detail for maize Bt 11 .

In the application of maize 1507, exposure was evaluated for non-target Lepidoptera by estimating the predicted environmental concentration based on pollen expression levels. The sensitivity data $\left(\mathrm{LD}_{50}\right)$ were calculated from toxicological studies of 16 lepidopteran species which, with the exception of the Monarch butterfly, were all pest species [16]. For maize 59122, the B. thuringiensis toxin concentration in different plant tissues and organisms was calculated and a 'formal' exposure assessment according to the US EPA Guidelines for the ERA was carried out.

The effects of the toxin expressed in the GMPs on NTOs were assessed at different levels of containment (laboratory, greenhouse or field). In $100 \%$ of the applications, the effects of $B$. thuringiensis proteins on NTOs were evaluated in laboratory studies using a standard set of test species representing a typical toxicological testing regime, e.g. as used for pesticide testing. Most testing was carried out using honeybees, earthworms, green lacewings, parasitic hymenoptera and ladybird beetles (see [14]). Generally, the isolated bacteria-expressed 
Table 5 Studies assessing exposure of NTOs and the adverse effects of GMPs on NTOs

\begin{tabular}{|c|c|c|c|c|c|c|}
\hline GMP & $\begin{array}{l}\text { Exposure assessed } \\
\text { in ERA }\end{array}$ & $\begin{array}{l}\text { Lab } \\
\text { studies }\end{array}$ & $\begin{array}{l}\text { Greenhouse } \\
\text { studies }\end{array}$ & $\begin{array}{l}\text { Field } \\
\text { studies }\end{array}$ & $\begin{array}{l}\text { Tritrophic } \\
\text { studies }\end{array}$ & $\begin{array}{l}\text { Species of conservation concern/aesthetical/ } \\
\text { cultural value }\end{array}$ \\
\hline Maize MON810 & - & Y & - & Y & - & - \\
\hline Maize $B t 11$ & Y & Y & - & Y & - & $-(M, O)^{e}$ \\
\hline Maize 1507 & Y & $Y^{a}$ & - & Y & - & $Y(M)$ \\
\hline Maize NK603 & - & Y & Y & - & Y & - \\
\hline Maize 59122 & Y & Y & - & Y & $Y^{d}$ & $Y(M)$ \\
\hline $\begin{array}{l}\text { Maize } 1507 \times \\
\text { NK603 }\end{array}$ & - & $Y, N^{b}$ & - & Y & - & - \\
\hline $\begin{array}{l}\text { Maize NK603 } \times \\
\text { MON810 }\end{array}$ & - & $Y, N^{c}$ & - & - & - & $-(M)$ \\
\hline
\end{tabular}

Only field studies with the respective GMP were considered.

Lab studies, with isolated proteins/parts of the GMP; greenhouse studies and field studies, with whole plants; $Y$, study conducted by the applicant or by order of the applicant; N, reference to assessment in other applications;'-', no data presented or applicant referred only to the published literature; M, Monarch butterfly; $\mathrm{O}$, other.

${ }^{a}$ Three of the nine studies cited are missing in the application; ${ }^{b}$ reference to a single-event application of maize 1507 ; ${ }^{c}$ reference to single-event applications of maize MON810 and maize NK603; ${ }^{d}$ study not attached to the application; ${ }^{e}$ reference to published studies, no toxicological studies submitted by the applicant.

proteins were fed to the test organisms. Additionally, pollen (e.g. ladybird beetles, honeybees, daphnids); protein suspensions (honeybees, adult ladybirds and parasitic hymenoptera); moth eggs coated with bacteriaderived protein solutions (green lacewings); or soils amended with bacteria-produced proteins (earthworms, springtails) were used. The same laboratory toxicity tests were submitted in different applications of different $B$. thuringiensis maize expressing the same class of toxins (e.g. Cry $1 \mathrm{Ab}$ ) without taking into account possible event-specific differences. The measured parameters related mostly to mortality and, therefore, acute toxicity. The endpoints used were no-observed-effect-concentration [NOEC], $\mathrm{LC}_{50}$ or unspecified 'signs of toxicity'. Depending on the species assessed, sublethal parameters were measured in $0 \%$ (parasitic hymenoptera, fish), 20\% (bees), 25\% (pest Lepidoptera), 33.3\% (daphnids, green lacewing larvae), 40\% (earthworms, coccinellids), 50\% (carabids, aphids), 80\% (collembola) and 100\% (mammals, birds and flower bugs) of the laboratory studies with NTOs presented in the applications [14].

Only data on NK603, a GMHT maize, were generated in the semi-controlled greenhouse experiments. None of the IR maize was equally evaluated under greenhouse conditions (see [14]). In 57\% of the applications, the GMP was assessed in field studies for potential non-target effects under European conditions (Tables 5 and 6). The plots used in these field studies were generally small or contained only a few plants (see [14]). Sampling of NTOs was either done using different types of traps (pitfall or sticky traps, beating of plants) or by visual inspection of the plants. Either the abundance of the organisms was recorded or a simple inventory list of species compiled.

Tritrophic studies were provided in two $(29 \%)$ of the applications (GM maize lines 59122 and NK603). However, the study provided for GM maize 59122 lacked a verification of the toxin uptake by the prey and the natural enemy species, respectively. Species of conservation concern or of aesthetical and cultural value were considered in $57 \%$ of the applications (Table 5). In all these cases, the Monarch butterfly (Danaus plexippus) was considered. For maize $B t 11$, the applicant additionally cited Lepidoptera listed in Annex IV of the Habitats Directive $92 / 43 /$ EEC without providing any toxicity data or detailed risk assessment.

Potential secondary pests, i.e. pest species replacing the target organism and being largely insensitive to the

Table 6 Studies assessing the adverse effects of GMPs on NTOs under field conditions

\begin{tabular}{|c|c|c|}
\hline GMP & US: Locations (years) & EU: Locations/country (years) \\
\hline Maize MON810 & 2 (1993); 2 (1994); 3 (1995) & 2/FR (1995) \\
\hline Maize $B t 11$ & 4 (1997-1998), 2 (1998-19999), 4 (1998-1999), 2 (2000-2001) & - \\
\hline Maize 1507 & $1(1999)$ & 2/ES (2002); 1/FR (2000) \\
\hline Maize NK603 & - & - \\
\hline Maize 59122 & $2(2001,2002)$ & 1/ES (2006); 1/HU (2006); 2/ES (2005) \\
\hline Maize $1507 \times$ NK603 & - & 1/ES (2005) \\
\hline Maize NK603 × MON810 & - & - \\
\hline
\end{tabular}

Only field studies with the respective GMP were considered.

$'-$, no study submitted 
respective toxin, were not considered in any of the applications. For maize Bt11, secondary infestations of maize by pathogens such as Fusarium sp. were discussed. The applicants of the two stacked event maize applications referred to the risk assessments submitted in the single-event applications. As for TOs, no further tests with NTOs and the stacked GMP event or the combination of the bacteria-derived toxins expressed in the stack were conducted.

Of the GM maize applications, 57\% contained studies carried out by the applicant with the respective GMP under field conditions in Europe (Table 6). European studies were conducted in one or two countries at one or two locations per country. In two cases, field studies were mentioned, but data of the respective studies were not shown (maize NK603 and NK603 × MON810). Additionally, applicants referred to published field studies on the NTO effects of B. thuringiensis crops. However, the respective GMP used in the literature was generally not indicated when the applicant cited published studies for the discussion of the potential adverse effects of the GMP on NTOs. Applicants also referred to studies in which not the respective GMP that was the subject of the requested approval was used. For example, for $B t 11$ maize, the applicant presented a summary report of various surveys of NTOs in B. thuringiensis maize fields. This report was not specifically compiled for $B t 11$ but for the registration of B. thuringiensis corn by US authorities and consequently contained studies with different $B$. thuringiensis maize events. Five of the 16 studies were conducted with $B t 11$ maize. From the total of 16 studies, five were conducted in Europe, however none of these with maize Bt11. Concerning maize NK603, seven field studies were cited, but six of these dealt with other GM crop species such as HT soybean or HT wheat. The studies cited for stacked event maize applications generally dealt with the single-event GMPs.

\section{Discussion}

From our analyses of seven GM maize applications, we conclude that the submitted data for ERA are incomplete and many crucial aspects regarding ecology and biostatistics are not addressed. Interactions between the GMP and its receiving environments are not sufficiently taken into consideration, and only a few field trials were carried out in Europe. Furthermore, in the field trials conducted in Europe, few aspects relevant to the ERA were included. The field assessments focussed mainly on agronomic rather than on ecological parameters. A range of consequences for the different components of the ERA result from these shortcomings. The most important ones will be discussed in the following sections.

\section{Agronomic evaluations of the GMPs lack scientific depth and standardized protocols}

The methods and parameters used for the evaluation of the agronomic characteristics of the GMPs varied considerably between the applications. We propose to use standardized parameters and/or methods for the assessment of any potential agronomic differences between the GM maize and its non-GM control. This is particularly relevant for the assessment of insect damage. The assessment parameters 'difference to other insects' or 'infestation', as employed in many applications, cannot be considered as sufficient for the demonstration of the efficacy of the GMP regarding different insect pests. The assessed insect pest species were often not specified, and rarely quantitative assessments with the respective GMP were made. In addition, some of the GM maize applications entirely lacked evaluations of pest susceptibility under European conditions.

A standardized methodology to assess potential differences between the GMP and the control plant in the susceptibility to common and locally important pest species is urgently needed for applications of GM maize with IR traits. Existing methods for the evaluation of pest infestation applied in the evaluation of plant varieties or the authorisation of plant protection products may also be helpful for reporting and evaluating relevant pests of GMPs [17-20]. For GMPs, such methods should be specifically adapted or developed to give applicants a clear guidance.

\section{Definition of target organisms not consistent with insect resistance management plans}

Regarding the assessment of effects on and mediated by TOs in the applications, the criteria applied to define TOs for IR maize remain unclear. For example, in some cases, all maize-feeding Lepidoptera were considered TOs. Defining the 'target' (and 'non-target') pests for a specific insect-resistant GMP is not trivial. A lepidopteran-active $B$. thuringiensis toxin may work well only against some out of several lepidopteran pest species that co-occur on the same crop. For instance, in the USA, the GM maize varieties expressing the Cry1Ab toxin are most effective against the European corn borer, but show lesser insecticidal activity against Spodoptera spp. For pest control purposes, Spodoptera species are not necessarily 'targets' because they are not reliably controlled below a damage threshold. In our view, TOs should include only those species that are aimed at being controlled by the respective GMP and for which the efficacy of the IR crop has been demonstrated. All others should be classified as non-target pest species.

Therefore, defining the TO for insect-resistant GM crops should clearly distinguish which lepidopteran 
pests are targeted in combination with the proven efficacy of the GMP for each specific pest. This should include a delineation of pest species which are not the primary targets of the GMP but may or are known also to be affected by the GM trait. The potential of the development of new major pests and resistance development in these species should also be included in the evaluation. This is necessary for reasons of quality control, product liability and resistance management.

The identification of the $\mathrm{TO}(\mathrm{s})$ for a particular $B$. thuringiensis maize event by the applicants was not consistent with the submitted insect resistance management [IRM] plans for B. thuringiensis crops. These were exclusively focused on $O$. nubilalis or $D$. v. virgifera, respectively. Other pest species, even if listed as TOs, such as Sesamia spp., were always left unconsidered in IRM plans. Especially lepidopteran pest species that may be affected to a lesser degree by $B$. thuringiensis toxins (e.g. Spodoptera spp., Agrotis spp.) [21,22] might develop resistance fairly quickly. A pest species may be classified as a 'non-target pest' for pest control purposes if it is not reliably controlled by a particular $B$. thuringiensis crop (e.g. Spodoptera spp.), but as a 'target' from the perspective of the insect resistance manager if it is sublethally affected. Hence, a careful definition and justification of what is a target and a non-target pest is important as it has implications for the evaluation of the interactions of GMPs with NTOs.

\section{Efficacy of the GMP not tested in the field}

Efficacy data are a basic element in the assessment of effects on and mediated by TOs and are as well important for the evaluation of the interactions of GMPs with NTOs. For B. thuringiensis maize expressing the Cry1Ab or Cry1F protein, only in $20 \%$ of the applications were the target pest species O. nubilalis and Sesamia sp. evaluated in the field (maize 1507; Tables 3 and 4). For maize 59122, no field data were presented providing evidence that this GM maize is effective in the field against its coleopteran TO as the insects evaluated in the field were not indicated in the application (Table 3). Hence, there is no information whether maize 59122 is actually controlling its TO under representative field conditions in Europe.

In our view, especially with IR crops, the abundance of not only the target but also non-target pest species should play an important role in the selection of the field trial locations considering different GM crop performances due to differential pest infestations and damaging levels [23-25]. Reporting local target pest densities is also relevant for understanding the baseline infestation rates in the respective regions. As insect or weed pressure may vary depending on regional characteristics, local conditions or years, these must be considered as well. No information was provided in the applications as to whether the background infestation levels of the TOs in the control plants were sufficient to demonstrate the efficacy of the product. This is important not only for the quality control of the GMP but also for balancing the positive desired effect of the treatment (i.e. the TO control) against any potential adverse environmental effects. If no sufficient control under certain agronomic conditions can be demonstrated, it is questionable whether the risk for resistance development or of the adverse environmental effects of the GMP is acceptable.

For example, plant protection products have to be tested under relevant circumstances where the TO has been shown to be present at a level causing adverse effects on an unprotected crop [26]. We suggest gaining the necessary data in the course of the agronomic evaluation of the GMP in relevant and representative locations of the different receiving environments. This would allow judging whether or not the GMP is effective in the envisaged cultivation area and under different agronomic conditions. Moreover, it would allow the identification of those production regions with the highest pest pressure.

In addition, there is an urgent need for the development of standardized procedures that specify which tissues and growth stages of the GMP for each relevant target pest should be tested. We recommend drafting respective guidance for IR GMPs. Guidelines for plant protection products which could be adapted to GMPs are currently available [19].

\section{Efficacy of the GMP not adequately assessed in the laboratory}

For the assessment of effects on and mediated by TOs, data on the efficacy and on the basic biological effects (e.g. mortality, development time, fecundity, etc.) of the GMPs for all listed target pests are essential. In the laboratory studies submitted in order to demonstrate the efficacy of the $B$. thuringiensis maize events (Table 4), applicants generally tested the bacteria-produced GM proteins instead of the GM plant. By using only purified bacterial proteins in optimized diets, any plant/toxin interactions are excluded, the potential bioactivity of smaller fragments of $B$. thuringiensis proteins, e.g. as found in maize MON810, are overlooked [27], and the variability in toxin concentrations in planta [28] is not taken into consideration (see also [7]).

Additionally, these lab studies often included pest species that do not occur as pests in Europe (e.g. corn earworm Helicoverpa zea, tobacco budworm Heliothis virescens, fall armyworm Spodoptera frugiperda). In all but one case of IR maize expressing a lepidopteranactive toxin (maize 1507), the applicants failed to 
evaluate the efficacy of the respective proteins to Sesamia sp., a pest common in the south of Europe. Only $67 \%$ of the studies for maize expressing a coleopteranactive toxin (maize 59122) assessed the relevant TO occurring in Europe, the Western corn rootworm, $D . v$. virgifera. For maize MON810 and the corresponding stacked maize NK603 $\times$ MON810, neither studies with O. nubilalis nor Sesamia spp. were submitted.

\section{Non-consideration of the required broad-spectrum herbicides and their potential effects on the receiving environment}

TOs were only identified for GMPs with IR traits, but not for HT traits. As a consequence, the effects of the GMP-herbicide complex on weeds were not assessed in any of the applications. However, the effects on weeds are relevant for the evaluation of the interactions of the GMP with NTOs. In our view, this reflects one of the largest deficiencies of the current regulation of HT GMPs - the exclusion of adverse effects caused by the altered management and use of the corresponding broad-spectrum herbicide. To our understanding, this is in clear contradiction to the requirements of Directive 2001/18/EC recommending an assessment of such indirect effects $[1,15]$.

As a consequence, potential differences in the agronomic or environmental performance of HT maize compared with conventional maize due to the application of the non-selective herbicide were not addressed in any of the applications. Data on the performance and efficacy of the HT GMP under field conditions, for instance an evaluation of whether GMHT maize would require different herbicide regimes at different times and the consequences of that for the flora and fauna in agroecosystems, were not submitted. The Farm Scale Evaluations demonstrated that herbivores, detritivores, and many of their predators and parasitoids in arable systems are sensitive to the changes in weed communities that result from the introduction of new herbicide regimes [29-32]. Changes in herbicide use are known to be major driving forces for the intensification affecting biodiversity in European agricultural landscapes [33-35] (see also [36] for GMHT crops). In this respect, it has to be emphasised that weed communities differ significantly between continents, countries or even agricultural regions; hence, any evaluation should consider regional differences and include plant species growing in the agricultural environment being of national or regional conservation concern. However, none of these were taken into consideration in GMHT maize applications. Also, resistance development in weeds was left unconsidered within the ERAs. This is in contrast to the GM maize with IR traits where the resistance development of TOs has been considered as the most important (agronomic) risk associated with the cultivation of such GMPs.

Applicants generally shift the responsibility for the assessment of potential adverse environmental effects due to the use of the complementary herbicide to the authorisation of the herbicide according to Directive 91/ 414/EEC [26]. We believe that considerable improvements in the ERA of GMHT crops could be made if applicants would include some information on the relevant plant protection product to be used with the GMHT crop submitted according to Directive 91/414/ EEC. This concerns in particular details on the application of the plant protection product (rate, timing, instructions for use, etc.), information on the toxicological profile including potential metabolites and data on the efficacy of the product including resistance risks. This information should also be available to authorities under Directive 2001/18/EC when cultivation of a GMHT crop is envisaged. Otherwise, an assessment of changed management procedures as recommended in Directive 2001/18/EC cannot be conducted.

\section{Inadequate approach for the evaluation of interactions of the GMP with NTOs}

The current approach for the assessment of the effects on NTO applied by the applicants in the applications reviewed is based on the assumption that a GMP consists of two parts that function in a linear additive fashion: the crop and the novel GM transgene product. Based on the substantial equivalence concept and when no statistically relevant compositional changes are detected, the crop plant as such is declared as safe and, consequently, only the added transgene product is subject to testing in the ERA. This approach to the assessment of NTOs is highly disputed in the scientific community [6,37-40] and fails to comply with the provisions put forward by Directive 2001/18/EC [41,7]. A consequence of this interpretation of the legal and scientific requirements for ERA is that clear risk research hypotheses are often not formulated and tested for the GMP in question. Hence, the assessment lacks a well-founded exposure analysis of the GMP in its receiving environments and meaningful testing of the selected NTOs from these environments.

In the reviewed applications, only a few applicants carried out an exposure assessment for the respective GMP (Table 5). The expression values used were either not based on values derived from European field trials or were considered in pollen only. For example, the exposure values of maize 59122 were based on the expression values of one toxin only (Cry34Ab1), although the pesticidal action of this event depends on the binary toxins Cry34Ab1/Cry35Ab1 [42]. Once grown commercially, GMPs and GMP transgene products are released 
into the environment and may affect target and NTOs via different pathways. Even after harvest, the novel proteins will remain in different environmental compartments and affect organisms in different environmental media or at different trophic levels [43-47]. A wellfounded assessment of potential exposure routes constitutes an important first step in this ERA category. As for the regulation of plant protection products according to Directive 91/414/EEC, an analysis of the distribution, fate, and behaviour of the GMP and parts of the GMP, together with its transgenic products in the environment, should be self-evident also for GMPs.

The assessment of the potential effects of the GMP on NTOs generally comprised few standard laboratory trials with the isolated bacteria-derived GM protein. Ecotoxicity testing of the protein in the absence of the plant context has been discussed in detail in the full report [14] and by other authors [7,48,49]. Neither greenhouse studies nor tritrophic studies were consistently provided, thus not taking any risks to predators of herbivores feeding on GMPs into consideration. The few field studies provided for evaluating potential adverse effects on NTOs were designed as stand-alone trials with no connecting research hypotheses linking laboratory and/or greenhouse studies with field studies.

Assessment of the potential adverse effects of a GMP on NTOs is a key element of the ERA. Its quality significantly depends on the careful identification of potentially exposed NTOs and meaningful testing in different containment steps. Concepts have been developed on how to select organisms from the receiving environments which would not dramatically increase the complexity of the ERA but significantly increase the scientific rigour and robustness of the results obtained $[41,49]$. These concepts comprise an exposure assessment, the selection of functional groups and the classification according to their biological functions. The goal is to focus on species which have an important functional role in a particular cropping system. Impacts on those species by GMP cultivation would actually result in an adverse environmental effect. The selected organisms should be used in toxicological tests in the laboratory, in the greenhouse or in field studies using the whole plant [50-52].

\section{Protected species are left unconsidered in the ERA}

Species, which are EU-wide, nationally or regionally endangered and/or protected may be of particular concern if GMPs interfere with their life cycles, habitats, competitors or food resources. Directive 2001/18/EC and its guidelines [15] specifically address endangered species. However, protected species have not been seriously considered in any of the GM maize applications. This fact, however, has implications for the evaluation of the interactions of the GMP with NTOs. The only substitute species mentioned in B. thuringiensis maize applications is the Monarch butterfly, a species with virtually no relevance for European ecosystems. Even for maize 59122, which expresses a coleopteran-active protein, no non-pest, endangered or protected coleopteran species was considered.

We propose that the selected species for NTO testing should include key species which allow the evaluation of possible consequences for species of conservation concern. This may include species that are biologically or taxonomically close to endangered or protected species for which a thorough exposure assessment is necessary. Due to their vulnerability, highly protected species should not undergo toxicity testing. The lowest NOEC for sublethal effects for species ecologically or taxonomically close to endangered species should be used in the risk evaluation. Because the protection goal for those species differs compared with other NTOs, we strongly advise using assessment factors different from those used to assess overall biodiversity effects. The application of safety margins on the NOEC will then give an indication of the risk for a particular protected species.

However, the distribution of endangered or threatened organisms varies within Europe. For butterflies in Central Europe for instance, most threatened species can be found in eastern France, eastern Austria, the Romanian Carpathians and eastern Poland [53]. Threatened butterfly species as well as their protection status may also vary depending on the country [54]. So for the selection of relevant organisms, identification of regional differences in the protection status of particular species may be useful. Such species should be particularly considered during the ERA. Otherwise, ways must be found giving EU MS the necessary competence to address risks for endangered and protected species before GMOs are commercially placed on the market.

\section{Field assessments do not take place in representative environments}

Field trials for agronomic evaluations of the GMPs took place overseas, in Europe or in both continents. The number of European countries (ranging from none to four, mostly two) and the number of locations within a specific country varied considerably between applications. Field studies for the assessment of potential effects on NTOs were more often conducted overseas than in Europe. Rarely was a specific assessment done in the same country and at the same location over two consecutive years. The choice of the locations was never justified by the applicants and the characterisation of the locations insufficient to judge their representativeness for European agronomic conditions. 
We conclude that the analysed applications failed to adequately consider receiving environments relevant in the EU and therefore do not fulfil the requirements of Directive 2001/18/EC. The choice of field trial locations, however, is considered crucial in terms of representativeness for the agronomic and environmental conditions the GMP is expected to encounter when commercially cultivated. European environments differ substantially in biotic and abiotic conditions such as in the occurrence of TOs (e.g. Sesamia spp.) or NTOs, the number of generations of TOs (e.g. one or two generations of $O$. nubilalis), agricultural practices and agronomic structures (e.g. nitrogen input), cultivation systems (e.g. low-tillage farming), crop rotation practices or climatic conditions. These factors will influence adverse effect scenarios and as such are relevant for all three assessment categories analysed. Some effects may become evident only at a regional level. Toxin levels in the GMP and the infestation rates of target pests are influenced not only by soil management practices such as increased nitrogen levels [55-57] but also by other agricultural management practices such as planting time and irrigation $[25,58]$. In this respect, consideration of a sufficient number of growing seasons is important to take account of the variability of biotic (e.g. pest pressure) and abiotic (e.g. weather conditions) environmental factors.

Directive 2001/18/EC [1] and its guidance notes [15] address the necessity to provide data from different environments where the GMO will be used; hence, the potential receiving environment is emphasised (site-bysite or region-by-region principle) [15]. Since the authorisation of GMPs so far included all EU countries, it needs to reflect the full range of biogeographic regions. Hence, we consider it paramount that any GMP is tested for its performance, efficacy and potential adverse environmental effects under various and representative environmental conditions in Europe. This view is also in line with EFSA which requires that 'multiple geographical locations representative of the various environments in which the GMPs will be cultivated should be covered' [3]. In our view, the selection of representative environments in which a particular GMP will be tested has to be made at the beginning of the data collection of the ERA taking into account important agronomic and environmental factors. During this selection, considerations should be given to already existing concepts such as the agro-climatic zones for plant protection products [19], the European biogeographical regions mentioned in Directive 92/43/EEC [8] and the indicative map of European biogeographical regions developed for assistance to the Natura 2000 process [59].

\section{No consideration of trait interactions}

Applications of GMPs derived from traditional crossing of two single-event GMPs (stacked event GMPs) generally referred to the assessments of the respective parental, single-event GMPs. Specific testing using the stacked event GM maize were hardly presented and potential interactions of transgene products when expressed in the same plant not addressed by the applicants. However, these interactions are relevant for the assessment of effects on and mediated by TOs as well as the evaluation of the interactions of the GMP with NTOs. Additionally, this approach ignores the legal requirements of the 'case-by-case' approach of Directive $2001 / 18 /$ EC as well as scientific knowledge. For example, B. thuringiensis toxin interactions towards invertebrates, when bacteria-expressed but also when expressed in GMPs (e.g. in case of maize 59122), are well known, but constantly ignored in the current risk assessment practice of stacked GMPs (for a review, see [60]).

Stacked GM hybrids also need to undergo individual testing in the ERA. As for single-event GMPs, this testing should be guided by formulated research hypotheses and meaningful testing of the stacked GMP in different levels of containment to comply with the legislative requirements and the case-by-case principle of Directive 2001/18/EC.

\section{Conclusions}

From the evaluation of the data presented for the three assessment categories in GM maize applications, we conclude that there is a need for an improvement of the ERA and its data base if cultivation is envisaged. This requires a broader ERA concept that includes a thorough exposure analysis and the scientific evaluation of the whole GMP at different containment levels guided by testable risk hypotheses. Risk conclusions should be based on relevant data specifically generated for and using the GM event in question. Basic information on the agronomic characteristics and the efficacy of the GMP as well as its environmental behaviour must be provided for the ERA. The corresponding herbicide and its agronomic and environmental consequences also need to be taken into account. Such an approach would significantly strengthen the risk conclusions and their credibility.

Careful attention ought to be paid to the consideration of relevant data obtained from different European environments. Here, guidance for the selection of representative locations for field trials assessing the agronomic and environmental characteristics of the GMP is urgently needed. There is also a strong need for the development of standards with respect to the test designs, methods and parameters to achieve a common 
approach for specific assessments, e.g. the evaluation of the efficacy of the GMP against its target organism. Such standards could significantly improve the ERA without overruling the case-by-case approach.

The aforementioned shortcomings have led to considerable dispute among EU MS, in particular regarding the data gaps and uncertainties in the ERAs. Nevertheless, the presented data were frequently considered sufficient in EFSA GMO panel opinions and the GMP declared safe with respect to potential effects on the environment. This apparent discrepancy in the perception of environmental risks can only be resolved if a common understanding of how an ERA should be performed and which scientific data should be included will be achieved. In our view, the addressed suggestions would significantly improve the quality of the ERAs of GM maize applications and hence fulfil the requirements of Directive 2001/18/EC. EFSA has recently made an important step forward in updating the guidance on ERA in collaboration with all stakeholders [61]. This updated guidance is now under scrutiny by the MS.

\section{End Note}

${ }^{a}$ The new EFSA guidance document comprises substantial modifications and additional issues (e.g. long-term effects, field trials, receiving environment). Work on supplementary guidance (e.g. post-market environmental monitoring) has not yet been finalized. The work described in this article has been carried out quite long before the publication of the new EFSA guidance, but is still relevant for the discussion process on how to implement the ERA guidance as a legally binding requirement by the EC. In this manuscript, some of the discrepancies between the legal requirements and the data basis used for the ERA by applicants at the time of the validness of the 'old' EFSA guidance have been presented. No reevaluation of these applications in light of the new ESFA guidance document is envisaged by EFSA. Hopefully, in the future, the new ESFA guidance, soon in place, will reduce such discrepancies and contribute to a more robust data basis for the ERA of GMO applications.

\section{Acknowledgements}

This study was supported by funding from the German Federal Environment Ministry (BMU) via the research and development project FKZ: 80664007 and is comprehensively documented in [14].

\section{Author details}

'Umweltbundesamt GmbH, Spittelauer Laende 5, 1090 Vienna, Austria ${ }^{2}$ Ecostrat GmbH, Hottingerstrasse 32, 8032 Zurich, Switzerland ${ }^{3}$ Bundesamt für Naturschutz, Konstantinstrasse 110, 53179 Bonn, Germany

\section{Authors' contributions}

$M D$ and MM drafted the manuscript with the help of MO. MD and MM analysed the data presented in the ERA of the GMP notifications for their relevance regarding the regulatory requirements. $\mathrm{ME}$ and $\mathrm{AHi}$ contributed to this part with a focus on the molecular characterisation and NTO, respectively. $\mathrm{AHi}, \mathrm{AHe}, \mathrm{BT}, \mathrm{HG}, \mathrm{MD}$ and $\mathrm{MO}$ conceived the study and participated in its the design. MD, MM and MO participated in the coordination of the study. All authors critically revised and contributed to the manuscript.

\section{Competing interests}

The authors declare that they have no competing interests.

Received: 11 March 2011 Accepted: 3 November 2011

Published: 3 November 2011

\section{References}

1. European Commission: Directive 2001/18/EC of the European Parliament and of the Council of 12 March 2001 on the deliberate release into the environment of genetically modified organisms and repealing Council Directive 90/220/EEC - Commission Declaration. 2001, 1-39, OJ L 106.

2. Regulation (EC) No. 1829/2003 of the European Parliament and of the Council of 22 September 2003 on genetically modified food and feed. 2003, 1-23, OJ L 268.

3. European Food Safety Authority (EFSA): Guidance document of the Scientific Panel on Genetically Modified Organisms for the risk assessment of genetically modified plants and derived food and feed. The EFSA Journal 2006, 99:1-100.

4. Regulation (EC) No. 1830/2003 of the European Parliament and of the Council of 22 September 2003 concerning the traceability and labeling of genetically modified organisms and the traceability of food and feed products produced from genetically modified organisms and amending Directive 2001/18/EC. 2003, 24-28, OJ L 268.

5. European Commission: Communication from the Commission to the European Parliament, the Council, the Economic and Social Committee and the Committee of the Regions on the Freedom for Member States to decide on the cultivation of genetically modified crops., COM (2010) 380 final.

6. Andow DA, Hilbeck A: Science-based risk assessment for non-target effects of transgenic crops. Bio-Science 2004, 54:637-649.

7. Hilbeck A, Meier M, Römbke J, Jänsch S, Teichmann H, Tappeser B: Environmental risk assessment of genetically modified plants - concepts and controversies. Environ Sci Eur 2011, 23:13.

8. Garcia-Alonso M, Jacobs E, Raybould A, Nickson T, Sowing P, Willekens H, van der Kouwe P, Layton R, Amijee F, Fuentes AM, Tencalla F: A tiered system for assessing the risk of genetically modified plants to nontarget organism. Environ Biosaf Res 2006, 5:57-65.

9. Romeis J, Bartsch D, Bigler F, Candolfi MP, Gielkens MMC, Hellmich RL, Huesing JE, Jepson PC, Layton R, Quemada H, Raybould A, Rose Rl, Schiemann J, Sears MK, Shelton AM, Sweet J, Vaituzis Z, Wolt JD: Assessment of risk of insect-resistant transgenic crops to non-target arthropods. Nat Biotechnol 2008, 26:203-208.

10. Report from the Commission to the Council and the European Parliament on the implementation of Regulation (EC) No. 1829/2003 of the European Parliament and of the Council on genetically modified food and feed. , COM (2006) 626 final.

11. Second Report from the Commission to the Council and the European Parliament on the experience of Member States with GMOs placed on the market under Directive 2001/18/EC on the deliberate release into the environment of genetically modified organisms. , COM (2007) 81 final.

12. Council of the European Union: Genetically modified organisms (GMOs) Council conclusions of 5 December 2008. 16882/08.

13. Evaluation of the EU Legislative framework in the field of cultivation of GMOs under Directive 2011/18/EC and Regulation (EC) No. 1829/2003: Interim Report. DG Environment. A report submitted by EPEC. November 2009.

14. Dolezel M, Miklau M, Hilbeck A, Eckerstorfer M, Heissenberger A, Gaugitsch H: Standardizing the environmental risk assessment of genetically modified plants in the EU. BfN Skripten 259 Bundesamt für Naturschutz, Bonn, Germany; 2009, 299[http://www.bfn.de/0301_veroe.html].

15. European Commission: Commission Decision of 24 July 2002 establishing guidance notes supplementing Annex II to Directive 2001/18/EC of the European Parliament and of the Council on the deliberate release into the environment of genetically modified organisms and repealing Council Directive 90/220/EEC. Official Journal of the European Communities, L 200/22. 2002/623/EC. 
16. Wolt JD, Conlan CA: Non-target exposure and risk assessment for cultivation of 1507 maize in Europe. Dow AgroSciences LLC Study ID: GH-C 52142001.

17. Bundessortenamt (BSA): Richtlinien zur Durchführung von landwirtschaftlichen Wertprüfungen und Sortenversuchen. Bundessortenamt 2000 [http://www.bundessortenamt.de/internet30/ fileadmin/Files/PDF/Richtlinie_LW2000.pdf]

18. European Commission: Directive 92/43/EEC: Council Directive of May 21st 1992 on the conservation of natural habitats and wild fauna and flora. 1996,63 , OJ L 59 .

19. Österreichische Agentur für Gesundheit und Ernährungssicherheit GmbH (AGES): Sorten und Saatgutblatt 2002. Methoden für Saatgut und Sorten gemäß §5 Abs. 1 Saatgutgesetz 1997, BGBI. I Nr. 72 zgd. BGBI. I Nr. 109/ 2001. Richtlinien für die Sortenprüfung. Schriftenreihe 59/2002 des BFL, 10. Jahrgang, Sondernummer 13

20. European and Mediterranean Plant Protection Organization (EPPO/OEPP): Standards on efficacy evaluation of plant protection products issued by EPPO/OEPP: Nr. PP1/13(3) Ostrinia nubilalis; Nr. PP1/214(1): Principles of acceptable efficacy; Nr. PP1/223(1): Introduction to the efficacy evaluation of plant protection products; Nr. PP 1/241: Guidance on comparable climates; Nr. PP1/152(3): Design and analysis of efficacy evaluation trials.

21. Püntener W: Manual für Feldversuche im Pflanzenschutz. Documenta CIBA-GEIGY AG Basel 1981, 145.

22. Demaagd R, Weemen-Hendriks M, Molthoff JW, Naimov S: Activity of wildtype and hybrid Bacillus thuringiensis d-endotoxins against Agrotis ipsilon. Arch Microbiol 2003, 179:367.

23. Binning RR, Rice ME: Effects of transgenic Bt corn on growth and development of the stalk borer Papaipema nebris (Lepidoptera: Noctuidae). J Econ Entomol 2002, 95:622-627.

24. Archer TL, Schuster G, Patrick C, Cronholm G, Bynum ED, Morrison WP: Whorl and stalk damage by European and southwestern corn borers to four events of Bacillus thuringiensis transgenic maize. Crop Prot 2000, 19:181-190.

25. Archer TL, Patrick C, Schuster G, Cronholm G, Bynum ED, Morrison WP: Ear and shank damage by corn borers and corn earworms to four events of Bacillus thuringiensis transgenic maize. Crop Prot 2001, 20:139-144.

26. Horner TA, Dively GP, Herbert DA: Development, survival and fitness performance of Helicoverpa zea (Lepidoptera: Noctuidae) in MON810 Bt field corn. J Econ Entomol 2003, 96:914-924.

27. European Commission: Directive 91/414/EEC: Council Directive of 15 July 1991 concerning the placing of plant protection products on the market. 1991, 1-32, OJ L 230

28. Rosati A, Bogani P, Santarlasci A, Buiatti M: Characterisation of $3^{\prime}$ transgene insertion site and derived mRNAs in MON810 YieldGard ${ }^{\circledR}$ maize. Plant Mol Biol 2008, 67:271-281.

29. Nguyen HT, Jehle JA: Quantitative analysis of the seasonal and tissuespecific expression of Cry1 $\mathrm{Ab}$ in transgenic maize MON810. J Plant Dis Prot 2007, 114:82-87

30. Brooks DR, Bohan DA, Champion GT, Haughton AJ, Hawes C, Heard MS, Clark SJ, Dewar AM, Firbank LG, Perry JN, Rothery P, Scott RJ, Woiwod IP, Birchall C, Skellern MP, Walker JH, Baker P, Bell D, Browne EL, Dewar AJ, Fairfax CM, Garner BH, Haylock LA, Horne SL, Hulmes SE, Mason NS, Norton LR, Nuttall P, Randle Z, Rossall MJ, Sands RJ, Singer EJ, Walker MJ: Invertebrate responses to the management of genetically modified herbicide-tolerant and conventional spring crops. I. Soil-surface-active invertebrates. Philos Trans R Soc Lond B Biol Sci 2003, 358:1847-1862.

31. Haughton AJ, Champion GT, Hawes C, Heard MS, Brooks DR, Bohan DA, Clark SJ, Dewar AM, Firbank LG, Osborne JL, Perry JN, Rothery P, Roy DB, Scott RJ, Woiwod IP, Birchall C, Skellern MP, Walker JH, Baker P, Browne EL, Dewar AJ, Garner BH, Haylock LA, Horne SL, Mason NS, Sands RJ, Walker MJ: Invertebrate responses to the management of genetically modified herbicide-tolerant and conventional spring crops. II. Withinfield epigeal and aerial arthropods. Philos Trans R Soc Lond B Biol Sci 2003, 358:1863-1877.

32. Hawes C, Haughton AJ, Osborne JL, Roy DB, Clark SJ, Perry JN, Rothery P, Bohan DA, Brooks DR, Champion GT, Dewar AM, Heard MS, Woiwod IP, Daniels RE, Young MW, Parish AM, Scott RJ, Firbank LG, Squire GR: Responses of plants and invertebrate trophic groups to contrasting herbicide regimes in the Farm Scale Evaluations of genetically modified herbicide-tolerant crops. Philos Trans R Soc Lond B Biol Sci 2003, 358:1899-1913.

33. Roy DB, Bohan DA, Haughton AJ, Hill MO, Osborne JL, Clark SJ, Perry JN, Rothery P, Scott RJ, Brooks DR, Champion GT, Hawes C, Heard MS, Firbank LG: Invertebrates and vegetation of field margins adjacent to crops subject to contrasting herbicide regimes in the Farm Scale Evaluations of genetically modified herbicide-tolerant crops. Philos Trans R Soc Lond B Biol Sci 2003, 358:1879-1898.

34. Krebs JR, Wilson JD, Bradbury RB, Siriwardena GM: The second Silent Spring? Nature 1999, 400:611-612.

35. Chamberlain DE, Fuller RJ, Bunce RGH, Duckworth JC, Shrubb M: Changes in the abundance of farmland birds in relation to the timing of agricultural intensification in England and Wales. J App/ Ecol 2000, 37:771-788.

36. Robinson RA, Sutherland WJ: Post-war changes in arable farming and biodiversity in Great Britain. J Appl Ecol 2002, 39:157-176.

37. Butler SJ, Vickery JA, Norris K: Farmland biodiversity and the footprint of agriculture. Science 2007, 315:381-383.

38. Birch ANE, Wheatley R, Anyango B, Arpaia S, Capalbo D, Getu Degaga E, Fontes E, Kalama P, Lelmen E, Lövei GL, Melo IS, Muyekho F, Ngi-Song A, Ochiendo D, Ogwang J, Pitelli R, Sétamou M, Sithanantham S, Smith J, Van Von N, Songa J, Sujii E, Quang Tan T, Wan F-H, Hilbeck A: Biodiversity and non-target impacts: a case study of Bt-maize in Kenya. In Environmental Risk Assessment of Genetically Modified Organisms. A Case Study of Bt Maize in Kenya. Volume 1. Edited by: Hilbeck A, Andow D. Wallingford: CAB International; 2004:117-185.

39. Andow DA, Lövei GL, Arpaia S: Ecological risk assessment for Bt crops. Nat Biotechnol 2006, 24:749-751.

40. Lang A, Lauber E, Darvas B: Early-tier tests insufficient for GMO risk assessment. Nat Biotechnol 2007, 25:35-36.

41. Andow DA, Zwahlen C: Assessing environmental risks of transgenic plants. Ecol Lett 2006, 9:196-214.

42. Hilbeck A, Andow DA, Arpaia S, Birch ANE, Chen Y, Fontes E, Fitt G, Lang A, Thi Thu Hong Le, Lövei GL, Manachini B, Nguyen TTC, Nguyen VH, Nguyen VT, Pham Van Lam, Van Toan Pham PC, Sujii E, Khuong Lai Trac UE, Wheatley R, Wilson L, Zwahlen C: Non-target and biological diversity risk assessment. In Environmental Risk Assessment of Transgenic Organisms. Volume 4: Challenges and Opportunities with Bt Cotton in Vietnam. Edited by: Andow DA, Hilbeck A, Nguyen VT. Wallingford: CABI Publishing; 2008:

43. Herman RA, Scherer PN, Young DL, Mihaliak CA, Meade T, Woodsworth AT, Stockhoff BA, Narva KE: Binary insecticidal crystal protein from Bacillus thuringiensis, strain PS149B1: effects of individual protein components and mixtures in laboratory bioassays. J Econ Entomol 2002, 95:635-639.

44. Baumgarte $S$, Tebbe CC: Field studies on the environmental fate of the $\mathrm{Cry} 1 \mathrm{Ab} B t$-toxin produced by transgenic maize (MON810) and its effect on bacterial communities in the maize rhizosphere. Mol Ecol 2005, 14:2539-2551.

45. Wandeler $\mathrm{H}$, Bahylova J, Nentwig W: Consumption of two Bt and six nonBt corn varieties by the woodlouse Porcellio scaber. Basic Appl Ecol 2002, 3:357-365

46. Rosi-Marshall EJ, Tank JL, Royer TV, Whiles MR, Evans-White M, Chambers C, Griffiths NA, Pokelsek J, Stephen ML: Toxins in transgenic crop byproducts may affect headwater steam ecosystems. PNAS 2007, 104:16204-16208.

47. Harwood JD, Wallin WG, Obrycki JJ: Uptake of Bt endotoxins by nontarget herbivores and higher order arthropod predators: molecular evidence from a transgenic corn agroecosystem. Mol Ecol 2005, 14:2815-2823.

48. Harwood JD, Samson RA, Obrycki JJ: Temporal detection of Cry1Abendotoxins in coccinellid predators from fields of Bacillus thuringiensis corn. Bull Entomol Res 2007, 97:643-648.

49. Hilbeck A, Meier M, Raps A: Review of non-target organisms and Bt plants. Ecostrat Report, Commissioned by Greenpeace International, Amsterdam 2000 [http://www.greenpeace.org/raw/content/international/ press/reports/review-on-non-target-organisms.pdf].

50. Hilbeck A, Jänsch S, Meier M, Römbke J: Analysis and Validation of Present Ecotoxicological Test Methods and Strategies for the Risk Assessment of Genetically Modified Plants. BfN Skripten 236, 116 pp. + Appendices Bonn, Germany: Bundesamt für Naturschutz; 2008.

51. Andow DA, Hilbeck A, Van Tuat Nguyen, (Eds): Environmental risk assessment of genetically modified organisms: challenges and opportunities with Bt cotton in Vietnam. Wallingford: CAB International; 20084. 
52. Hilbeck $A$, Nelson $K$, Andow DA, Underwood E: Problem formulation and options assessment (PFOA) to assess the ecological risks associated with a GM crop. In Risk, Hazard, Damage - Specification of Criteria to Assess Environmental Impact of Genetically Modified Organisms. Volume 1. Edited by: Breckling B, Verhoeven R. Naturschutz und Vielfalt 1; 2004:131-143.

53. Van Swaay C, Cuttelod A, Collins S, Maes D, López Munguira M, Šašic M, Settele J, Verovnik R, Verstrael T, Warren M, Wiemers M, Wynhof I: European Red List of Butterflies Luxembourg: Publications Office of the European Union; 2010.

54. Van Swaay CAM, Warren MS: Red Data book of European butterflies (Rhopalocera) Nature and Environment, No. 99. Strasbourg: Council of Europe Publishing; 1999.

55. Hilbeck A, Fontes E, Andow DA: Environmental Risk Assessment of Transgenic Organisms. Volume 2: A Case Study of Bt Cotton in Brazil Wallingford: CAB International; 2006.

56. Phelan PL, Mason JF, Stinner BR: Soil-fertility management and host preference by European corn borer, Ostrinia nubilalis (Hübner), on Zea mays L.: a comparison of organic and conventional chemical farming. Agric Ecosyst Environ 1995, 56:1-8.

57. Bruns HA, Abel CA: Nitrogen fertility effects on $B t$ delta-endotoxin and nitrogen concentrations of maize during early growth. Agron J 2003, 95:207-211.

58. Bruns HA, Abel CA: Effects of nitrogen fertility on Bt endotoxin levels in maize. J Entomol Sci 2007, 42:35-43.

59. European Topic Centre on Biological Diversity (ETC/BD): Indicative Map of European Biogeographical Regions: Methodology and Development European Topic Centre on Biological Diversity under contract with the European Environment Agency, Paris; 2006.

60. Spök A, Dolezel M, Eckerstorfer M, Freigassner M, Gaugitsch H, Heissenberger A, Karner S, Klade M, Proksch M, Schneider L, Treiber F, Uhl M: Assessment of toxic and ecotoxic properties of novel proteins in GMOs Bundesministerium für Gesundheit, Familie und Jugend, Forschungsberichte der Sektion IV, Band; 2008, 189.

61. EFSA Panel on Genetically Modified Organisms (GMO): Guidance on the environmental risk assessment of genetically modified plants. EFSA J 2010, 8(11):1879[http://www.efsa.europa.eu/en/gmo/gmoguidance.htm], [111 pp.].

doi:10.1186/2190-4715-23-33

Cite this article as: Dolezel et al: Scrutinizing the current practice of the environmental risk assessment of GM maize applications for cultivation in the EU. Environmental Sciences Europe 2011 23:33.

\section{Submit your manuscript to a SpringerOpen ${ }^{\mathcal{O}}$ journal and benefit from:}

- Convenient online submission

- Rigorous peer review

- Immediate publication on acceptance

- Open access: articles freely available online

- High visibility within the field

- Retaining the copyright to your article

Submit your next manuscript at $\gg$ springeropen.com 